\title{
Susceptibility to Laurel Wilt and Disease Incidence in Two Rare Plant Species, Pondberry and Pondspice
}

S. W. Fraedrich, Southern Research Station, USDA Forest Service Athens, GA 30602; T. C. Harrington, Department of Plant Pathology, Iowa State University, Ames, IA 50011; C. A. Bates, Georgia Forestry Commission, Statesboro, GA 30461; J. Johnson, Georgia Forestry Commission, Athens, GA 30602; L. S. Reid, South Carolina Forestry Commission, Columbia, SC 29221; G. S. Best, Southern Research Station, USDA Forest Service Athens, GA 30602; T. D. Leininger and T. S. Hawkins, Southern Research Station, USDA Forest Service, Stoneville, MS 38776

\begin{abstract}
Fraedrich, S. W., Harrington, T. C., Bates, C. A., Johnson, J., Reid, L. S., Best, G. S., Leininger, T. D., and Hawkins, T. S. 2011. Susceptibility to laurel wilt and disease incidence in two rare plant species, pondberry and pondspice. Plant Dis. 95:1056-1062.

Laurel wilt, caused by Raffaelea lauricola, has been responsible for extensive losses of redbay (Persea borbonia) in South Carolina and Georgia since 2003. Symptoms of the disease have been noted in other species of the Lauraceae such as the federally endangered pondberry (Lindera melissifolia) and the threatened pondspice (Litsea aestivalis). Pondberry and pondspice seedlings were inoculated with $R$. lauricola from redbay, and both species proved highly susceptible to laurel wilt. Field assessments found substantial mortality of pondberry and pondspice, but in many cases the losses were not attributable to laurel wilt. $R$. lauricola was isolated from only 4 of 29 symptomatic pondberry plants at one site, but the fungus was not recovered from three plants at another site. $R$. lauricola was isolated from one of two symptomatic pondspice plants at one site, and from five of 11 plants at another site,

produced by Xyleborus glabratus (the vector of laurel wilt), were found in some pondberry and pondspice stems, but adults were not found. Damage caused by Xylosandrus compactus was found in pondberry stems, but this ambrosia beetle does not appear to be a vector of $R$. lauricola. Xyleborinus saxeseni adults were found in a dying pondspice with laurel wilt, and $R$. lauricola was recovered from two of three adults. Isolates of $R$. lauricola from pondberry, pondspice, and $X$. saxeseni had rDNA sequences that were identical to previously characterized isolates, and inoculation tests confirmed that they were pathogenic to redbay. Because pondberry and pondspice tend to be shrubby plants with small stem diameters, these species may not be frequently attacked by $X$. glabratus unless in close proximity to larger diameter redbay.
\end{abstract} but not from any plant at a third site. Insect bore holes, similar to those
Widespread mortality of redbay (Persea borbonia (L.) Spreng.) has been observed in the coastal plains of South Carolina and Georgia since 2003 (3). The mortality is due to a disease known as laurel wilt caused by Raffaelea lauricola T.C. Harrin., Fraedrich \& Aghayeva, a fungal symbiont that serves as a food source for the redbay ambrosia beetle, Xyleborus glabratus Eichhoff (Coleoptera: Curculionidae: Scolytinae) $(3,9,10)$. The beetle is native to Asia (e.g., India, Japan, and Taiwan), where it is often associated with plant species in the Lauraceae (e.g., Cinnamomum osmophloem Kanehira, Lindera latifolia Hk.f., and Litsea elongata (Nees) Hk.f.) $(11,31)$, and the beetle brought the laurel wilt pathogen with it from Asia (11). The redbay ambrosia beetle was first detected in the vicinity of Savannah, GA in 2002, and mortality of redbay in nearby Hilton Head, SC was noted soon thereafter (3). The pathogen causes a vascular wilt disease similar to the wilt caused by the related Dutch elm disease fungi (Ophiostoma ulmi and $O$. novoulmi), which also have vectors in the subfamily Scolytinae (3). Wilted redbay trees of suitable diameter sustain large populations of $X$. glabratus in outbreak areas $(3,5)$. Female $X$. glabratus carry $R$. lauricola and other fungal symbionts in specialized mandibular

Corresponding author: Stephen Fraedrich, E-mail: sfraedrich@fs.fed.us

Accepted for publication 12 April 2011

doi:10.1094/PDIS-11-10-0841

This article is in the public domain and not copyrightable. It may be freely reprinted with customary crediting of the source. The American Phytopathological Society, 2011 sacs called mycangia, in which the symbionts grow in a yeast phase $(8,9)$. The beetle may introduce the pathogen into healthy trees during what are believed to be aborted attacks, often on branches too small for development of beetle brood (3).

Since the initial discovery of laurel wilt on redbay (3), the disease was diagnosed on other plant species in the Lauraceae occurring in coastal plain areas of the Southeast. Most notably, sassafras (Sassafras albidum (Nuttall) Nees) and avocado (Persea americana Mill.) were reported as hosts in areas with diseased redbay, and both species proved susceptible to $R$. lauricola in inoculation studies $(3,16)$. The disease has been a serious concern for the conservation of two other indigenous members of the Lauraceae, pondberry (Lindera melissifolia (Walter) Blume) and pondspice (Litsea aestivalis (L.) Fern.), both of which are rare because of habitat loss. Pondberry is a dioecious, deciduous, rhizomatous, clonal shrub that grows up to $2 \mathrm{~m}$ tall and occurs at the margins of ponds, swamps, and sinks $(1,22)$. Pondberry is listed as a federally endangered species and is extremely rare in the Southeast. In the 1990s, only five populations of pondberry were identified in South Carolina (25), and four populations were identified in Georgia (20). Pondspice is a dioecious, deciduous, multibranched shrub that grows 0.5 to $3 \mathrm{~m}$ tall, and this species also grows at the margins of ponds and swamps $(18,22)$. This species is known to occur in only 13 Georgia counties (20) and five counties in South Carolina (22). Pondspice is listed as a candidate for the federal endangered species list and is considered threatened in Georgia and South Carolina.

$R$. lauricola has been isolated from pondberry and pondspice plants with wilt-like symptoms $(3,24)$, but there is no information on the susceptibility of these species, and the potential impact of the disease on these species is not known. The objectives of this 
study were to: (i) determine the susceptibility of pondberry and pondspice to $R$. lauricola; (ii) compare pondberry and pondspice isolates of $R$. lauricola to redbay isolates using morphology and rDNA sequences; and (iii) document the occurrence of laurel wilt and potential vectors in pondspice and pondberry in areas of South Carolina and Georgia where these rare plants are in proximity of redbay plants with laurel wilt.

\section{Materials and Methods}

Susceptibility of pondberry and pondspice to $R$. lauricola. Susceptibility was evaluated in controlled growth chamber experiments. Pondberry plants were produced from seeds from an Arkansas source (Craighead County), and seedlings were grown in a greenhouse in pots $\left(3,000 \mathrm{~cm}^{3}\right)$ with a peat:sand mixture $(2: 1)$ for approximately 1.5 years. The plants had an average shoot length of $140 \mathrm{~cm}$ and a diameter at ground line of $7.5 \mathrm{~mm}$ at the time of inoculation. Pondspice seeds were collected in Effingham County, GA, and seedlings were grown in a greenhouse for approximately one year in pots $\left(2,500 \mathrm{~cm}^{3}\right)$ with a peat:sand mixture $(2: 1)$. Shoot length at inoculation averaged $64 \mathrm{~cm}$, and the average diameter at ground line was $6.0 \mathrm{~mm}$. Two isolates of $R$. lauricola (HH5 and FTG1 = C2428 and C2258, respectively, in the collection of T. C. Harrington) obtained from wilted redbay trees on Hilton Head Island, SC, and Fort George Island, FL, were used for inoculations. Isolates were single spored and subsequently grown on malt extract agar (MEA, 2.5\% malt extract and $2.0 \%$ agar) at $25^{\circ} \mathrm{C}$ for 10 to 14 days prior to inoculations. Conidia were collected as previously described (3). Spore concentrations were determined with a hemacytometer and ranged from 1.6 to $2.2 \times 10^{6}$ conidia $/ \mathrm{ml}$.

Fifteen pondberry and 15 pondspice seedlings were wounded by drilling 2-mm-diameter holes into stems just above ground line to a depth of approximately one-half the diameter of the stem. Five seedlings of each species were inoculated with $0.2 \mathrm{ml}$ of the conidial suspension from isolate $\mathrm{C} 2428$, and another five seedlings of each species were inoculated with isolate C2258. Five seedlings of each species served as controls, and $0.2 \mathrm{ml}$ of sterile distilled water was placed into the wounds. Inoculation points on all seedlings were wrapped with Parafilm M (Pechiney Plastic Packaging, Menasha, WI). Seedlings were placed in a growth chamber with 16 $\mathrm{h}$ of light per day, with day and night temperatures set at $28^{\circ} \mathrm{C}$ and $25^{\circ} \mathrm{C}$, respectively. Plants were watered every 2 to 4 days, as needed. After 5 to 7 weeks, disease symptoms were evaluated, and pieces of stem tissue from 10 to $20 \mathrm{~cm}$ above the inoculation points were surface sterilized and plated on cycloheximide-streptomycin malt agar (CSMA, $1 \%$ malt extract, $1.5 \%$ agar, and 200 ppm cycloheximide and $100 \mathrm{ppm}$ streptomycin sulfate added after autoclaving), a medium selective for Ophiostoma spp. and their related anamorphs such as Raffaelea spp. $(6,7,9)$.

Field evaluations of laurel wilt in pondberry and pondspice. Resource and conservation managers in South Carolina and Georgia were consulted for possible locations of pondberry and pondspice within the main infestation areas of $X$. glabratus and laurel wilt in redbay. During 2006 and 2007, two sites with living pondberry were visited, including one site at the Marine Corps Air Station in
Beaufort County, SC and another near Clyo in Effingham County, GA. Three sites with pondspice were also visited during 2006 and 2007, and these sites were located on Lady's Island in Beaufort County, SC, at Fort Stewart in Bryan County, GA, and near Clyo, GA in Effingham County. Other sites reported to have pondberry or pondspice were examined between 2006 and 2009 in Wheeler and Bryan counties in Georgia, and Beaufort and Berkeley counties in South Carolina, but these sites were unsuitable for these studies.

Pondberry and pondspice plants were examined for wilt, dieback, or other signs and symptoms of disease or injury. Symptomatic plants were found at each site, but no attempt was made to determine overall incidence of mortality. At each site, a sample of plants was selected that had recently wilted leaves or branch or stem dieback with xylem discoloration, symptoms similar to those of laurel wilt on redbay (3). Plants examined in the field but found to have excessively dry xylem and phloem tissues were usually discarded because $R$. lauricola is difficult to isolate from such dead tissues. Samples were placed in plastic bags and stored in coolers with ice packs until they could be examined and processed.

In the laboratory, samples of branches and stems were examined for sapwood discoloration and evidence of insect damage, insects, or other stress-related factors. Sections of branches and stems with dieback or sapwood discoloration were surface sterilized by dipping in $95 \%$ ethanol and flaming. Wood chips were removed from samples and placed on MEA and CSMA. Evaluations of isolation plates were typically performed 7 to 10 days after plating samples.

Small-diameter pondberry stems were split longitudinally in half with hand pruners to expose tunnels made by insects. Sections of pondspice branches and stems with insect holes were split longitudinally in half with a hammer and chisel, and then split as necessary to expose openings of ambrosia beetle tunnels. A thin piece of straw was pushed through tunnels to extract beetles.

Association of $\boldsymbol{R}$. lauricola with ambrosia beetles. Three adult Xyleborinus saxeseni (Ratzeburg) beetles and two adult Xylosandrus crassiusculus (Motschulsky) beetles were recovered from symptomatic pondspice stems at the Effingham County site in April 2007. The beetles were individually ground and dilution plated on CSMA or SMA (malt extract agar with 100 ppm streptomycin) to determine if they were carrying $R$. lauricola or other fungal symbionts $(9,11)$. Two of the $X$. saxeseni beetles were surface sterilized prior to grinding (9), but the other beetle was not treated. The $X$. crassiusculus beetles were not treated before grinding and dilution plating. The numbers of colony forming units of $R$. lauricola per beetle were expressed as the mean of the three plates (9). Samples of individual colonies were transferred to MEA, hyphal tipped, and stored for additional evaluation.

Pathogenicity and characterization of $R$. lauricola isolates. Isolates of $R$. lauricola obtained from pondberry and pondspice at the Effingham County site were evaluated for pathogenicity in July 2007. Four isolates, two from pondberry (Lindera 1 and $6=\mathrm{C} 2356$ and $\mathrm{C} 2358$, respectively) and two from pondspice (Litsea 1 and $4=$ $\mathrm{C} 2353$ and $\mathrm{C} 2355$, respectively), were tested. An isolate $(\mathrm{SAX} 1=$ $\mathrm{C} 2445$ ) of $R$. lauricola from an adult, female $X$. saxeseni, excavated from a pondspice plant, was also tested. Isolates were grown

Table 1. Incidence of Raffaelea lauricola and ambrosia beetle tunnels in dead and dying pondberry (Lindera melissifolia) stems at two locations in South Carolina and Georgia

\begin{tabular}{|c|c|c|c|c|c|}
\hline $\begin{array}{l}\text { Location } \\
\text { (county, state) }\end{array}$ & Sampling date & $\begin{array}{c}\text { Symptomatic plants } \\
\text { sampled }^{\mathrm{a}}\end{array}$ & $\begin{array}{l}\text { R. lauricola } \\
\text { isolated }^{\mathbf{b}}\end{array}$ & $\begin{array}{l}\text { Samples with ambrosia } \\
\text { beetle tunnels }\end{array}$ & $\begin{array}{l}\text { Samples with tunnels } \\
\text { caused by } X \text {. compactus }\end{array}$ \\
\hline Beaufort, SC & 29 March 2006 & 3 & 0 & 3 & 3 \\
\hline \multirow[t]{3}{*}{ Effingham, GA } & 23 August 2006 & 12 & 4 & 3 & 3 \\
\hline & 6 April 2007 & 4 & 0 & 0 & 0 \\
\hline & 14 June 2007 & 13 & 0 & 6 & 5 \\
\hline Total plants sampled & & 32 & 4 & 12 & 11 \\
\hline
\end{tabular}

\footnotetext{
${ }^{a}$ Recently killed or wilting stems with xylem discoloration.

${ }^{\mathrm{b}} R$. lauricola isolated from discolored xylem.

${ }^{c}$ Tunnels with openings of small diameter, typical of those produced by ambrosia beetles such as Xylosandrus compactus or Xyleborus glabratus.

${ }^{\mathrm{d}}$ Tunnels in stem pith characteristic of those caused by $X$. compactus, with or without adult beetles present.
} 
on MEA and inoculum was produced as previously described. Inoculum concentrations ranged from 2.8 to $7.1 \times 10^{6}$ spores $/ \mathrm{ml}$. Pondspice and pondberry plants were not available, so pathogenicity of these isolates was confirmed on redbay seedlings. Four redbay plants were inoculated with each isolate (20 plants total), and four additional plants served as controls. Plants were inoculated as previously described, and seedlings were evaluated after 5 weeks. At the end of the experiment, pieces of stem tissue were subsequently removed from seedlings at 10 to $20 \mathrm{~cm}$ above the inoculation points, surface sterilized, and plated on CSMA to determine the presence of $R$. lauricola. Plates were evaluated after 8 to 10 days for $R$. lauricola.

Amplification and sequencing of the large subunit (LSU) rDNA was performed as described previously (8) on isolates of Raffaelea from pondberry, pondspice, and $X$. saxeseni, including isolates C2355, C2356, and C2445.
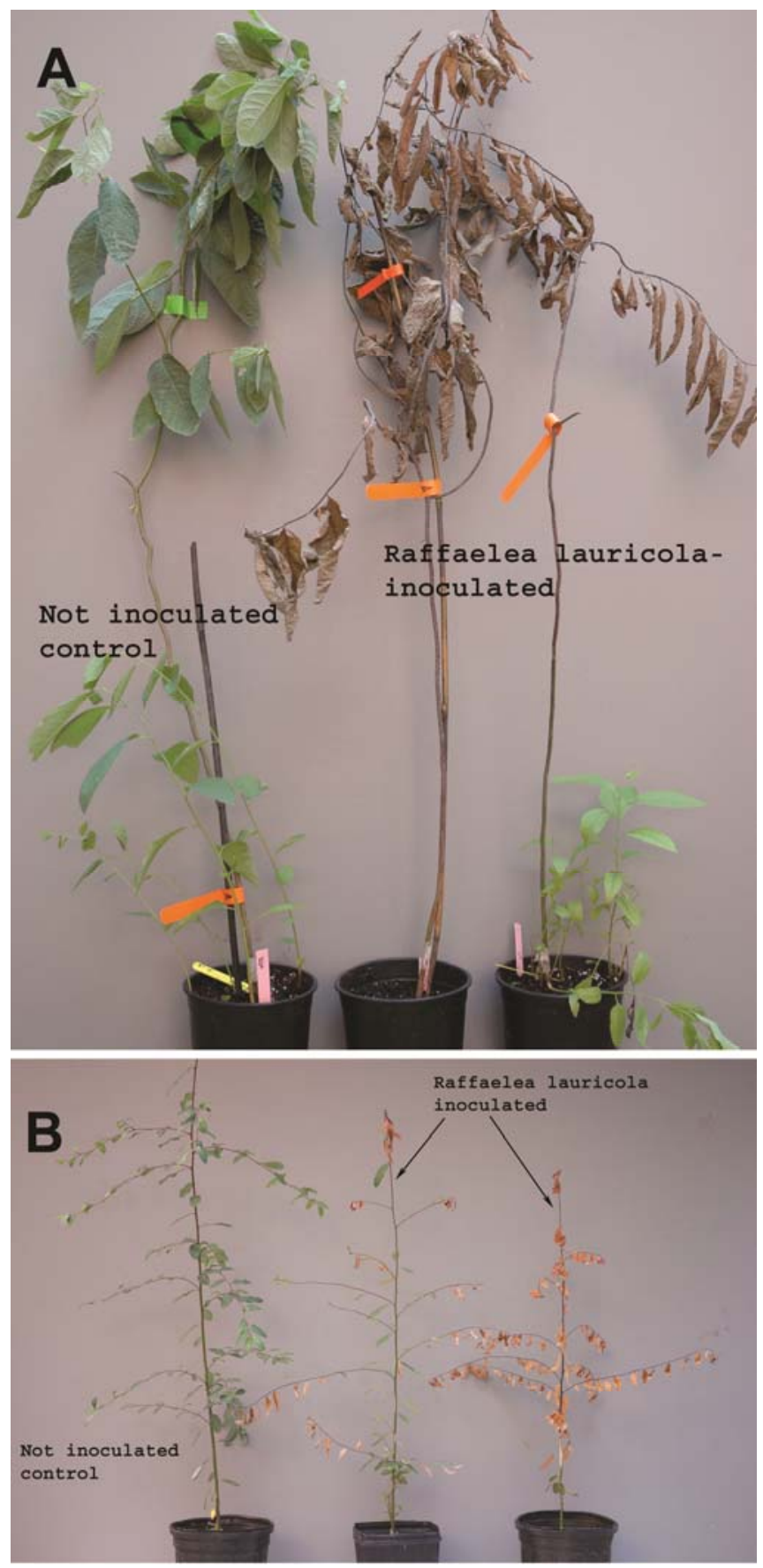

Fig. 1. Control and Raffaelea lauricola-inoculated $\mathbf{A}$, pondberry, and B, pondspice plants 5 and 7 weeks after inoculation, respectively.

\section{Results}

Susceptibility of pondberry and pondspice to $R$. lauricola. Ten of 10 pondberry plants inoculated with isolates of $R$. lauricola wilted and died within 5 weeks (Fig. 1A). All inoculated plants had xylem discoloration throughout the stems, and $R$. lauricola was recovered at the end of the experiment. All control plants remained healthy with no evidence of wilt symptoms, and $R$. lauricola was not isolated from these plants at the end of the experiment.
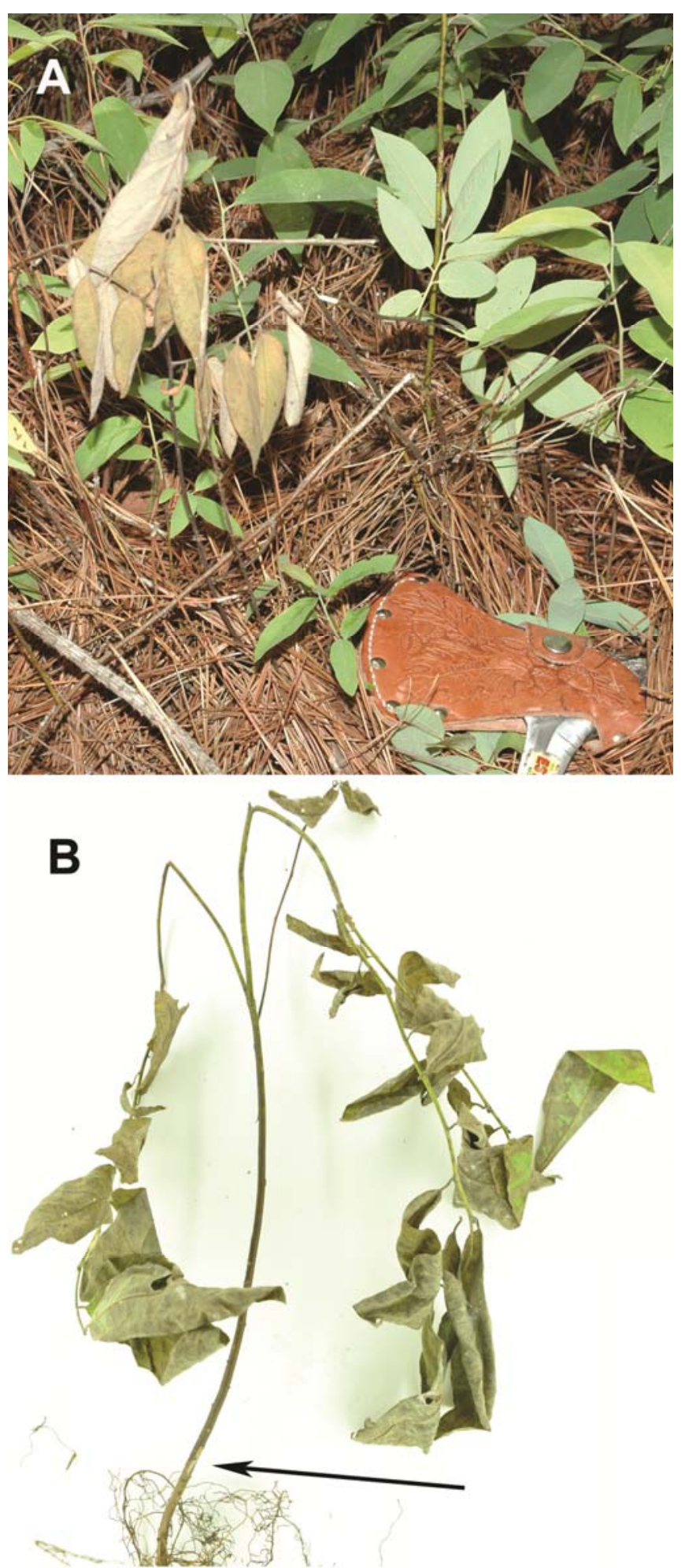

Fig. 2. Damage on pondberry caused by Xylosandrus compactus. A, Wilt-like symptoms, and B, beetle entry hole in stem above ground line (at arrow) on pondberry plant with wilt-like symptoms. 
Nine of 10 pondspice plants inoculated with $R$. lauricola also had dead and flaccid leaves within 7 weeks after inoculation (Fig. 1B). These wilted plants had xylem discoloration throughout their stems, and $R$. lauricola was recovered from discolored xylem tissues. One inoculated plant and all control plants remained healthy and had no xylem discoloration, and $R$. lauricola was not isolated from these plants at the end of the experiment.

Field evaluations, pondberry. A site with pondberry located in a flatwood forest in Beaufort County was visited in March 2006. Stem dieback and wilt-like symptoms were common on pondberry plants throughout the stand, but field assessments found that much of the damage was due to tunneling by the black twig borer, Xylosandrus compactus (Eichhoff) (Table 1, Fig. 2A and B), based on the identification of adult beetles excavated from the tunnels or the unique type of galleries (longitudinal tunnels running through the pith) (2). Samples from three pondberry plants with stem dieback were collected and plated on CSMA, but $R$. lauricola was not isolated.

A flatwood forest site in Effingham County was first visited in August 2006, and pondberry plants were located at the margins of intermittent ponds and depressions. Pondberry was common at this location, and there was scattered mortality or dieback of stems throughout the site. Stem samples were collected from 12 pondberry plants that ranged from 30 to $90 \mathrm{~cm}$ in height and from 2 to 8 $\mathrm{mm}$ in diameter at ground line. All of the stem samples had xylem discoloration, and 3 of the 12 plants had damage consistent with that caused by $X$. compactus. $R$. lauricola was isolated from discolored xylem of four of the 12 plants, but the discolored xylem in these samples was not associated with tunneling of $X$. compactus.
The plants from which $R$. lauricola was isolated were among the largest plants sampled.

The Effingham County site was revisited in April 2007, when four symptomatic pondberry plants were collected, and again in June 2007, when 13 symptomatic pondberry plants were sampled. The sampled plants exhibited dieback and xylem discoloration in stems, but $R$. lauricola was not isolated from any of the samples on either date. Evidence of ambrosia beetle damage was not found in the April 2007 samples, but five of the samples collected in June 2007 had insect galleries consistent with those caused by X. compactus.

Field evaluations, pondspice. All sites with pondspice were located in areas that had intermittent ponds, but the depressions were dry at the time of evaluation. Pondspice occurred primarily as multistemmed shrubs with stem heights up to $3 \mathrm{~m}$. Mortality, wiltlike symptoms, and dieback of stems were observed in some plants at all three locations, but $R$. lauricola was only isolated from plants at two of the three sites (Table 2).

One site with numerous pondspice plants in Beaufort County was first visited in March 2006. Although there were many dead stems with xylem discoloration scattered among healthy appearing stems, the phloem and xylem tissues of most of these stems were dry and had apparently died months before the visit. No attempt was made to isolate from these stems. One plant with a stem diameter of $25 \mathrm{~mm}$ had sapwood discoloration and appeared to have died recently, and $R$. lauricola was isolated from the discolored xylem tissue. The site was revisited in August 2006, but no recent stem mortality was apparent. A stem sample was collected from a plant that had xylem discoloration and small insect entrance

Table 2. Incidence of Raffaelea lauricola, ambrosia beetle tunnels, and adult ambrosia beetles in dead and dying stems of pondspice (Litsea aestivalis) at three locations in South Carolina and Georgia

\begin{tabular}{|c|c|c|c|c|c|}
\hline $\begin{array}{l}\text { Location } \\
\text { (county, state) }\end{array}$ & Date & $\begin{array}{c}\text { Symptomatic } \\
\text { plants sampled }^{\mathrm{a}}\end{array}$ & $\begin{array}{l}\text { R. lauricola } \\
\text { isolated }^{\mathbf{b}}\end{array}$ & $\begin{array}{l}\text { Samples with ambrosia } \\
\text { beetle tunnels }\end{array}$ & $\begin{array}{c}\text { Samples with ambrosia } \\
\text { beetles present }\end{array}$ \\
\hline \multirow[t]{2}{*}{ Beaufort, SC } & 29 March 2006 & 1 & 1 & 0 & 0 \\
\hline & 22 August 2006 & 1 & 0 & 1 & $1^{\mathrm{d}}$ \\
\hline Bryan, GA & 30 March 2006 & 6 & 0 & 5 & 0 \\
\hline \multirow[t]{3}{*}{ Effingham, GA } & 23 August 2006 & 5 & 2 & 3 & $1^{\mathrm{e}}$ \\
\hline & 6 April 2007 & 3 & 1 & 2 & $2^{\mathrm{f}}$ \\
\hline & 14 June 2007 & 3 & 2 & 1 & 0 \\
\hline Total plants sampled & & 19 & 6 & 12 & 4 \\
\hline
\end{tabular}

a Recently killed or wilting stems with xylem discoloration.

${ }^{\mathrm{b}} R$. lauricola isolated from discolored xylem.

${ }^{c}$ Tunnels with entrance holes of small diameter similar to those produced by Xyleborus glabratus.

${ }^{\mathrm{d}}$ Adult beetles were dead, dried out, and damaged, and they were not identified to species.

e Three adult beetles were identified as Xylosandrus crassiusculus, and one was identified as Xylosandrus compactus.

${ }^{\mathrm{f}}$ Three adult beetles from one sample were identified as Xyleborinus saxeseni, and two adult beetles from another sample were identified as Xylosandrus crassiusculus.
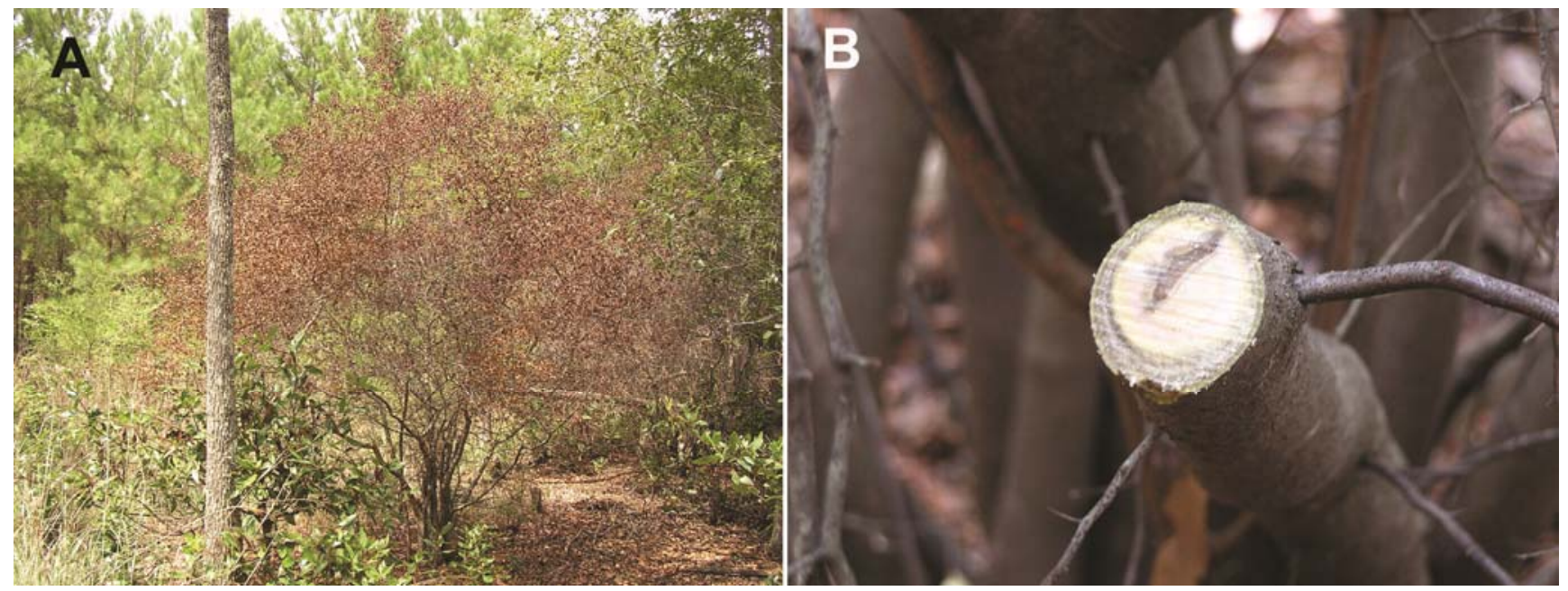

Fig. 3. Symptoms of laurel wilt on pondspice at a site in Effingham Co., GA. A, Wilted plant, and B, xylem discoloration in outer rings. 
holes similar to those produced by $X$. glabratus. A couple of adult beetles were found in the tunnels, but these were dead and damaged, and they could not be identified to species. R. lauricola was not isolated from the stem.

A site on the Fort Stewart Army Base in Bryan County was also visited in March 2006. Dieback and mortality was common in individual stems of many of the multistemmed pondspice plants. Discoloration often extended throughout the cross-sectional area of the xylem in portions of the affected stems, but vertical spread of the discoloration was often limited, with an abrupt transition zone between healthy and symptomatic xylem. Samples of stems and branches, ranging from 10 to $32 \mathrm{~mm}$ diameter, were collected from six plants. Beetle holes were found in stems of five of the six plants, but no beetles were found in the galleries. Attempts to isolate $R$. lauricola from the six plants were unsuccessful.

A third location with pondspice was located in Effingham County and was first visited in August 2006. Pondspice plants were numerous, and wilt-like symptoms and mortality were common among the multistemmed shrubs (Fig. 3A). Stem samples were collected from five plants that ranged from 15 to $32 \mathrm{~mm}$ in diameter, and beetle entrance holes were observed in samples from three of the five plants. Adult $X$. crassiusculus and X. compactus beetles were found in tunnels of one sample. Short tunnels $(2$ to $4 \mathrm{~mm}$ depth) were found in samples from two other plants, but these appeared to be aborted ambrosia beetle tunnels and not used for brood development. Stem samples from two of the five plants had dark brown streaks that were primarily restricted to the outer xylem rings (Fig. 3B), but other samples had discoloration that extended into the inner xylem rings. $R$. lauricola was isolated from the two plants with discoloration in the outer xylem rings.

The Effingham County site was revisited in April 2007, and branch and stem sections that ranged from 10 to $50 \mathrm{~mm}$ diameter were collected from three pondspice plants. A small diameter branch from one plant had beetle entrance holes, and adult $X$. crassiusculus beetles were extracted from the tunnels. A stem section (32 $\mathrm{mm}$ diameter) from a second plant had beetle entrance holes and tunnels with adult $X$. saxeseni beetles. Stem samples from a third plant had no evidence of beetle attack. Xylem discoloration in the samples ranged from streaking in the outer sapwood to discoloration that extended throughout the stem cross section. $R$. lauricola was isolated from the stem section that had the adult $X$. saxeseni, but the fungus was not isolated from the other plants.

A third visit was made to the Effingham County site in June 2007. Branch and stem sections ranging from 8 to $30 \mathrm{~mm}$ diameter were collected from three pondspice plants with wilt or dieback symptoms. Beetle entrance holes were observed in samples from one of the three plants, but neither adult beetles nor larvae were present in the tunnels. All samples had streaks of xylem discoloration in the outer xylem rings and, in some samples, discoloration that extended well into the older xylem rings. $R$. lauricola was isolated from two of the three plants.

Association of $\boldsymbol{R}$. lauricola with ambrosia beetles. $R$. lauricola was isolated from two of the three adult $X$. saxeseni beetles obtained from a pondspice plant at the Effingham County site in April 2007. R. lauricola was not isolated from one of the two X. saxeseni beetles that was surface sterilized, and the second surface-sterilized beetle yielded an estimated $133 \mathrm{cfu}$ of $R$. lauricola. The $X$. saxeseni that was not surface sterilized prior to plating yielded an estimated $600 \mathrm{cfu}$ of $R$. lauricola on CSMA. When this ground beetle slurry was plated on SMEA, 1,870 cfu of mycelial yeasts (Candida spp.) were estimated, in addition to 1,070 cfu of $R$. lauricola.

No Raffaelea species was isolated on SMEA from the two adult $X$. crassiusculus beetles collected from pondspice in Effingham County in April 2007. One of the beetles yielded an estimated 17,000 cfu of an Ambrosiella sp. similar to A. hartigii L.R. Batra (8) and 7,000 cfu of Candida spp. The second beetle yielded an estimated 11,000 cfu of Candida spp. but no Raffaelea or Ambrosiella $\mathrm{sp.}$

Pathogenicity and characterization of $\boldsymbol{R}$. lauricola isolates. All isolates of $R$. lauricola recovered from symptomatic pondberry and pondspice plants produced colonies that were initially mucoid on MEA plates. Hyphae growing in the agar or on the agar surface produced small conidiophores with clusters of conidia typical of $R$. lauricola $(3,10)$. Sequences of the LSU rDNA were obtained from 10 isolates from the Effingham County site: four isolates from pondberry, three isolates from pondspice, and three isolates from $X$. saxeseni adults excavated from pondspice stems. All of the isolates had partial rDNA sequences identical to those of other isolates of $R$. lauricola $(3,8,10)$.

All tested isolates of $R$. lauricola from pondberry, pondspice, and $X$. saxeseni were pathogenic to redbay seedlings. The 20 inoculated redbay seedlings (four seedlings for each of the five isolates of $R$. lauricola) wilted and developed xylem discoloration within 6 weeks, and $R$. lauricola was reisolated from all inoculated seedlings at the end of the experiment. Control seedlings remained healthy and did not have sapwood discoloration, and $R$. lauricola was not isolated from these plants.

\section{Discussion}

Laurel wilt may complicate conservation efforts for pondberry and pondspice. These rare species are highly susceptible to laurel wilt based on our growth chamber inoculation studies, and $R$. lauricola was recovered from some symptomatic plants of both species. However, many attempts to isolate the pathogen from dead and dying stems of pondberry and pondspice were not successful, and other biotic and abiotic factors also appear to be important causes of stem dieback and mortality as has been previously suggested $(1,17,24,25)$. Stem dieback of pondberry was frequently reported before laurel wilt was observed in the United States $(1,4,17,25)$ and has been attributed to drought, flooding, site disturbance, and various insects and potential pathogens $(1,4,25)$. Pondspice has not been studied as extensively as pondberry, but factors other than laurel wilt also probably contributed to some of the stem dieback and mortality of pondspice. $R$. lauricola was isolated from only one pondspice sample collected at the Beaufort County site, and it was not isolated from samples collected at the Bryan County site. We suspect that some of the dieback and mortality observed in this species were related to droughts that were severe in the area in the late 1990s and early 2000s $(13,23)$, and another period of drought began in early 2006 (13). Pondspice thrives in wet soils (15) and is usually found at pond margins (22), but intermittent ponds were dry with no evidence of recent flooding at the three sites that we visited in 2006 and 2007. Nevertheless, R. lauricola was isolated from five of 11 plants that appeared to have wilted recently at the Effingham County site, and laurel wilt can be a significant mortality factor on pondspice.

Fusarium and Botryosphaeria spp. have been isolated from pondberry and pondspice plants that did not have laurel wilt (S. W. Fraedrich, unpublished data), but it is not known if these potential pathogens were involved in the dieback and mortality. Xylosandrus compactus was clearly associated with mortality of pondberry plants at both locations assessed in this study. Botryosphaeria ribis Grossenb \& Duggar and X. compactus were also associated with dieback of pondberry in Mississippi $(26,27)$. An adult weevil subsequently identified as Heilipus apiatus Oliv. (F. Shockley, Department of Entomology, University of Georgia, personal communication) was found at the base of a pondspice plant at the Effingham County site in April 2007. Furthermore, scattered mortality and wilting pondberry plants were observed in several stands on the Francis Marion National Forest in South Carolina where laurel wilt had not been found, and some of these plants had extensive feeding damage in the root collar region and on major roots (S. W. Fraedrich, unpublished). A weevil larva similar in size and morphology to $H$. apiatus (28) was found on a pondberry plant at one of the sites. This weevil, known as the avocado weevil, is associated with plants in the Lauraceae, and larvae damage roots of avocado $(28,32)$ and have been associated with sassafras (12) and pondberry (25).

Xyleborus glabratus is known to carry $R$. lauricola in high numbers of colony forming units $(9,11)$ and is commonly found in dead 
and dying redbay, sassafras, and avocado trees afflicted with laurel wilt $(3,8,16)$. We were unable to find adult $X$. glabratus associated with pondspice and pondberry plants, even if $R$. lauricola was isolated from these plants. The failure to find brood galleries of $X$. glabratus may be due to the small diameter of pondberry and pondspice stems. Smaller diameter redbay seedlings and saplings are less frequently attacked and utilized by $X$. glabratus for brood than are larger diameter redbay trees $(3,5)$. However, aborted attacks by $X$. glabratus on small diameter branches of redbay are believed to be an important pathway for infection by $R$. lauricola (3), and some of the apparently aborted galleries found in pondberry and pondspice with laurel wilt were probably caused by $X$. glabratus adults that flew into the site from nearby redbay trees.

Redbay trees with laurel wilt occurred near our study sites, often within several hundred meters. However, the Effingham County site was unique in that it had redbay trees with laurel wilt within 5 to $10 \mathrm{~m}$ of some of the pondspice and pondberry plants, and this site had the highest incidence of laurel wilt in pondberry and pondspice. If redbay supporting large populations of $X$. glabratus are necessary for significant levels of laurel wilt to occur on pondspice and pondberry, the disease may not pose a great threat to these species after the large redbay trees have died, as is anticipated (5). Removal of large diameter redbay trees within $100 \mathrm{~m}$ of pondberry and pondspice populations may prove to be an effective management tool when trying to protect these species from laurel wilt.

$X$. compactus is an Asian ambrosia beetle that has been present in the southeastern United States since the 1940s, and the beetle attacks and kills twigs and small diameter branches of many plant species (2). The symptomatic pondberry plants examined in South Carolina and Georgia commonly had galleries typical of $X$. compactus, but we were not able to recover $R$. lauricola from samples with this type of damage. In areas with laurel wilt, we (S. W. Fraedrich and T. C. Harrington, unpublished) have been unable to isolate $R$. lauricola from $X$. compactus adults collected from redbay twigs and branches exhibiting dieback, and it is not believed to be an important vector of $R$. lauricola.

The association of $R$. lauricola with $X$. saxeseni suggests that the beetle could be a vector. However, the number of cfu of $R$. lauricola recovered from the beetles was low compared to recovery from $X$. glabratus (9), and the fungus may not be able to reproduce well in mycangia of $X$. saxeseni. Furthermore, there is no clear evidence to indicate that $X$. saxeseni can effectively transmit the pathogen to healthy plants. $X$. saxeseni is reported to be aggressive (21) and has caused economic losses (29), but this ambrosia beetle is primarily associated with recently cut, injured, or dying plants (30), and its role in the decline of plants is unclear $(14,19)$. X. saxeseni was introduced into the United States over 100 years ago, but to our knowledge, it has not been previously associated with attacks on pondspice, pondberry, or redbay.

Xylosandrus crassiusculus is often found in redbay trees with laurel wilt, but a pondspice stem at the Effingham County site, from which two $X$. crassiusculus beetles were extracted, did not have laurel wilt. Dilution plating of these two beetles on CSMA yielded no Raffaelea species, but an Ambrosiella species was isolated from one of the beetles. Other attempts to isolate $R$. lauricola from $X$. crassiusculus have also failed, and it has been speculated that the mycangium of this species does not support growth of Raffaelea spp. (8).

Biologists and land managers are concerned about the potential impacts of laurel wilt on pondspice and pondberry. As laurel wilt spreads on redbay, additional stands of pondberry and pondspice will be exposed to the disease, and the occurrence of wilt-like symptoms caused by insects or diseases other than laurel wilt will be a source of confusion for biologists evaluating the health of these species. Our experiences with laurel wilt indicate that populations of $X$. glabratus are not sustained on smaller diameter $(<2.5 \mathrm{~cm})$ redbay $(5)$, and in this study there was no clear evidence that the shrubby pondberry and pondspice are used for brood production. Management of $X$. glabratus populations to lessen the threat of laurel wilt may be possible through the removal of larger diameter redbays in and around stands of pondberry and pondspice. Continued monitoring of pondberry and pondspice as laurel wilt moves through the Southeast is imperative, and a better understanding of other disease and insect problems that affect these threatened and endangered species is also necessary to enhance the possibility of their long-term preservation.

\section{Acknowledgments}

We thank Floyd Shockley (University of Georgia, Athens) for identification of the adult Helipus apiatus on pondspice in Effingham County, GA, and James Hanula (U.S. Forest Service, Athens, GA) for identification of a weevil larva found on pondberry. We also greatly appreciate the assistance of Stella Osborn and Jeff Mangun (Wildlife and Forestry Branch Offices, Fort Stewart, GA), John Holloway (Planning Department, Beaufort County, SC), and Tom Patrick (Georgia Department of Natural Resource) in locating sites with pondspice and pondberry.

\section{Literature Cited}

1. Devall, M., Schiff, N., and Boyette, D. 2001. Ecology and reproductive biology of the endangered pondberry, Lindera melissifolia (Walt) Blume. Nat. Areas J. 21:250-258.

2. Dixon, W. N., and Woodruff, R. E. 1982. The black twig borer, Xylosandrus compactus (Eichhoff) (Coleoptera: Scolytidae). Entomol. Circ. 250. Fla Dep. Agric. Consum. Serv., Div. Plant Ind., Gainesville, FL.

3. Fraedrich, S. W., Harrington, T. C., Rabaglia, R. J., Ulyshen, M. D., Mayfield, A. E., Hanula, J. L., Eickwort, J. M., and Miller, D. R. 2008. A fungal symbiont of the redbay ambrosia beetle causes a lethal wilt in redbay and other Lauraceae in the southeastern United States. Plant Dis. 92:215-224.

4. Godt, M. J. W., and Hamrick, J. L. 1996. Allozyme diversity in the endangered shrub Lindera melissifolia (Lauraceae) and its widespread congener Lindera benzoin. Can. J. For. Res. 26:2080-2087.

5. Hanula, J. L., Mayfield, A. E., Fraedrich, S. W., and Rabaglia, R. J. 2008 Biology and host associations of redbay ambrosia beetle (Coleoptera: Curculionidae: Scolytinae), exotic vector of laurel wilt killing redbay trees in the southeastern United States. J. Econ. Entomol. 101:1276-1286.

6. Harrington, T. C. 1981. Cycloheximide sensitivity as a taxonomic character in Ceratocystis. Mycologia 73:1123-1129.

7. Harrington, T. C. 1992. Leptographium. Pages 129-133 in: Methods for research on soilborne phytopathogenic fungi. L. L. Singleton, J. D. Mihail, and C. M. Rush, eds. American Phytopathological Society. St. Paul, MN.

8. Harrington, T. C., Aghayeva, D. N., and Fraedrich, S. W. 2010. New combinations in Raffaelea, Ambrosiella, and Hyalorhinocladiella and four new species from the redbay ambrosia beetle, Xyleborus glabratus. Mycotaxon 111:337-367.

9. Harrington, T. C., and Fraedrich, S. W. 2010. Quantification of propagules of the laurel wilt fungus and other mycangial fungi from the redbay ambrosia beetle, Xyleborus glabratus. Phytopathology 100:1118-1123.

10. Harrington, T. C., Fraedrich, S. W., and Aghayeva, D. N. 2008. Raffaelea lauricola, a new ambrosia beetle symbiont and pathogen on the Lauraceae. Mycotaxon 104:399-404.

11. Harrington, T. C., Yun, H. Y., Lu, S. S., Goto, H., Aghayeva, D. N., and Fraedrich, S. W. 2011. Isolations from the redbay ambrosia beetle, Xyleborus glabratus, confirm that the laurel wilt pathogen, Raffaelea lauricola, originated in Asia. Mycologia. In press.

12. Hoffman, R. L. 2003. Heilipus apiatus, a striking large weevil new to the Virginia fauna (Coleoptera: Curculionidae). Banistera 22:58-59.

13. Klos, R. J., Wang, G. G., Bauerle, W. L., and Rieck, J. R. 2009. Drought impact on forest growth and mortality in the southeast USA: An analysis using Forest Health and Monitoring data. Ecol. Appl. 19:699-708.

14. Kovach, J., and Gorsuch, C. S. 1988. Response of young peach trees to Ambrosiella sulphurea, a symbiotic fungus of Xyleborinus saxeseni. Plant Dis. 72:225-227.

15. Kral, R. 1983. A report on some rare, threatened or endangered forest-related vascular plants of the South. U.S. Dep. Agric., For. Serv., Southern Region. Tech. Pub. R8, TP2. Atlanta, GA.

16. Mayfield, A. E., Smith, J. A., Hughes, M., and Dreaden, T. J. 2008. First report of laurel wilt disease caused by a Raffaelea sp. on avocado in Florida. Plant Dis. 92:976.

17. Morgan, S. 1983. Lindera melissifolium; A rare southeastern shrub. Nat. Areas J. 3:62-67.

18. Nelson, G. 1996. The shrubs and woody vines of Florida. Pineapple Press, Sarasota, FL.

19. Oliver, J. B., and Mannion, C. M. 2001. Ambrosia beetle (Coleoptera: Scolytidae) species attacking chestnut and captured in ethanol-baited traps in middle Tennessee. Environ. Entomol. 30:909-918.

20. Patrick, T. S., Allison, J. R., and Krakow, G. A. 1995. Protected plants of Georgia. Georgia Department of Natural Resources, Social Circle, GA.

21. Rabaglia, R. J., Dole, S. A., and Cognato, A. I. 2006. Review of American Xyleborina (Coleoptera : Curculionidae : Scolytinae) occurring North of Mexico, with an illustrated key. Ann. Entomol. Soc. Am. 99:1034-1056.

22. Radford, A. E., Ahles, H. E., and Bell, C. R. 1968. Manual of the vascular flora of the Carolinas. University of North Carolina, Chapel Hill, NC. 
23. Sun, G., Callahan, T. J., Pyzoha, J. E., and Trettin, C. C. 2006. Modeling the climatic and subsurface stratigraphy controls on the hydrology of a Carolina bay wetland in South Carolina, USA. Wetlands 26:567-580.

24. Surdick, J. A., and Jenkins, A. M. 2009. Pondspice (Litsea aestivalis) population status and response to laurel wilt disease in northeast Florida. Florida Natural Areas Inventory,Tallahassee, FL.

25. U.S. Fish and Wildlife Service. 1993. Recovery plan for pondberry (Lindera melissifolia). U.S. Fish and Wildlife Service, Atlanta, GA.

26. Wilson, A. D., Schiff, N. M., Devall, M. S., Connor, K. F., Hamel, P. B., Gardiner, E. S., and Leininger, T. D. 2004. Incidence and severity of Botryosphaeria stem canker and dieback of pondberry (Lindera melissifolia) in Mississippi. (Abstr.) Phytopathology 94:S110.

27. Wilson, A., Schiff, N., Leininger, T., Hamel, P., Gardiner, E., Connor, K., and Devall, M. 2005. Black twig borer exacerbates damage caused by Bot- ryosphaeria stem canker and dieback of pondberry in the Delta National Forest of Mississippi. (Abstr.) Phytopathology 95:S112.

28. Wolfenbarger, D. O. 1948. Heilipus squamosus Lec, A new enemy of the avocado. Proc. Fla. State Hortic. Soc. 61:260-268.

29. Wood. S. L. 1977. Introduced and exported American Scolytidae (Coleoptera). Great Basin Naturalist 37:67-74.

30. Wood, S. L. 1982. The bark and ambrosia beetles of North and Central America (Coleoptera: Scolytidae), a taxonomic monograph. Great Basin Naturalist Memoirs. No. 6. Brigham Young University, Provo, UT.

31. Wood, S. L., and Bright, D. E. 1992. A catalog of Scolytidae and Platypodidae (Coleoptera), Part 2: Taxonomic index, Volumes A and B. Great Basin Naturalist Memoirs No. 13. Brigham Young University, Provo, UT.

32. Woodruff, R. E. 1963. An avocado weevil (Heilipus apiatus Oliv.). Entomol. Circ. 11. Fla. Dep. Agric. Consum. Serv., Div. Plant Ind., Gainesville, FL. 